JOURNAL OF SECURITY AND SUSTAINABILITY ISSUES

ISSN 2029-7017 print/ISSN 2029-7025 online

2019 March Volume 8 Number 3

http://doi.org/10.9770/jssi.2019.8.3(17)

Scopus

\title{
ENSURING ENVIRONMENTAL SAFETY VIA WASTE MANAGEMENT
}

\author{
Viktoriya Anishchenko ${ }^{1}$, Viktoriya Marhasova ${ }^{2}$, Andrii Fedorenko $^{3}$, Mykhailo Puzyrov $^{4}$, Oleh Ivankov $^{5}$ \\ ${ }^{1 * 4,5}$ Academy of the State Penitentiary Service, Chernihiv, Honcha str. 34, Chernihiv, 14000, Ukraine \\ ${ }^{2,3}$ Chernihiv National University of Technology, 95 Shevchenka Str., 14027 Chernihiv, Ukraine
}

E-mail: 1*koaduep@gmail.com

Received 22 February 2018; accepted 20 January 2019; published 30 March 2019

\begin{abstract}
Criteria are determined that can be applied to recognize waste as economic resources. The criteria for recognition of waste as economic resources include the following: the existence of property rights, the possibility of sale, the receipt of economic benefits and the environmental effect. These criteria are the basis of a new understanding of this economic concept and the basis for shaping the behavior of economic agents in waste management. The proposed criteria have a significant impact on the formation of the accounting system for waste and waste management operations. The place of waste in the environmental safety management system is substantiated on the basis of determining the process of its generation at all stages of economic activity of an industrial organization and the directions of its management both at the internal and inter-economy level. A waste classification matrix is developed for identification and recognition purposes, which makes it possible to form an information space as the basis for making management decisions in the field of environmental safety of industrial organizations.
\end{abstract}

Keywords: circular economy, waste, security, economic benefits, concept of sustainable development, environmental effect

Reference to this paper should be made as follows: Anishchenko, V.; Marhasova, V.; Fedorenko, A.; Puzyrov, M.; Ivankov, O. 2019. Ensuring environmental safety via waste management, Journal of Security and Sustainable Issues 8(3): 507-519.

http://doi.org/10.9770/jssi.2019.8.3(17)

JEL Classifications: F52, O39

\section{Introduction}

The priority direction of development of environmental safety of large industrial organizations in the world is management of waste, which have anthropogenic impact on the environment. In the conditions of the dynamic development of science and technology, the need arises for the transformation of economic relations at different levels of economic systems and the "man-nature" relationships. This is especially true for waste management. Waste generation is an irresistible process that inevitably accompanies human activity. Waste generation stop is impossible even with the use of the most advanced technologies. The high level of its generation is a consequence of the inefficient use of natural resources in production activities. The experience of developed countries has shown that humanity can successfully develop by significantly reducing the consumption of natural resources per unit of production.

Scientists have made a significant contribution to the development of theoretical, methodological and organizational provisions for waste management. However, today there is still a number of theoretical and organizational-methodological problems that need to be solved at large industrial organizations to ensure their sustainable development and compliance with the provisions of the circular economy. In particular, the following problems require solutions: 
determination of the specifics of the current condition of waste management in the world and justification of the directions for its improvement in ensuring the environmental safety of large industrial organizations (Hilorme, T., Nazarenko Inna, Okulicz-Kozaryn, W., Getman, O. \& Drobyazko, S. (2018); Tetsman, I.; Bazienė, K.; Viselga, G. (2017); Dobrovolskienè, N.; Tvaronavičienè, M.; Tamošiūnienė, R. (2017); Novikovas, A.; Stankevičius, A. (2018); Imran, M., Jian, Z., ul Haque, A., Urbański, M., Nair, S.L.S. (2018); Dobrovič, J., Urbański, M., Gallo, P., Benková, E., Čabinová, V. (2018)Eddelani, O., El Amrani El Idrissi, N., Monni, S. (2019); Smaliukiene, R., Monni, S. (2019));

substantiation of the nature and classification of waste as an object of environmental safety management of an industrial organization (Rigamonti, L., Sterpi, I., \& Grosso, M. (2016));

determination of the essence, composition and specifics of waste management operations as a basis for the environmental safety management of an organization (Cucchiella, F., D’Adamo, I., \& Gastaldi, M. (2017)).

So, today waste is not only a concept in the natural, technical or geological sciences, but it is an economic category. Waste is an economic object, the management of which depends on the development of economic systems of both a separate organization and the country as a whole, and in some cases, individual regions. After all, waste is an integral component of production and interaction between the organization and the environment.

\section{Literature Survey}

Thus, waste as a result of production is considered in the works of many scientists. In particular, Vučijak, B., Kurtagić, S. M., \& Silajdžić, I. (2016) note that waste is an inevitable consequence of production, which is included in the price of goods and itself becomes a commodity, that is, a specific product of production, because it is involved in the structure of the production, consumption and accumulation system. In addition, the definition of waste in scientific works is limited to the remains of material resources generated in the production process. Regarding this, the approaches to the essence of waste as a result of production can be limited to the following: remains of material resources, as unsuitable for further use; secondary resources (Tetiana, H., Karpenko, L., Fedoruk, O., Shevchenko, I., \& Drobyazko, S. (2018)).

Today, in the industrialized countries of the world there is awareness that progress means not only an increase in labor productivity, but also an increase in the productivity of the material resources used while reducing their consumption. Countries with significant reserves of natural resources in recent years tend to reduce their extraction (Ravindran, R., \& Jaiswal, A. K. (2016)). It is economically more profitable to process own secondary resources than to develop new fields. Thus, a radical solution to the resource problems of metallurgy and improving the structure of the production of ferrous metals in the United States provides for an increase in the use of scrap and waste as the main alternative to primary iron ore raw materials (Zaman, A. U. (2016), Turner, D. A., Williams, I. D., \& Kemp, S. (2016)). The technological efficiency of recycling of secondary raw materials is beyond doubt. Using 1 ton of prepared ferrous scrap allows you to save more than 1.8 tons of ore, sinter and pellets, 0.5 tons of coke, $45 \mathrm{~kg}$ of fluxes, about 100 cubic meters of gas. This saves more than half of the energy required for steelmaking in the case of sequential processing of raw materials (iron ore) (Haupt, M., Vadenbo, C., \& Hellweg, S. (2017)). In general, characterizing these approaches, it should be noted that they consider waste unilaterally, and do not characterize its importance in environmental management and do not determine the directions of its management. After all, waste today is not only the remains of material resources, it is the result of an appropriate process associated with the use of a complex of economic resources, which, in turn, can bring economic benefits to business entities.

We consider it necessary during the study of waste as remains of material resources and secondary resources to determine it as the result of a certain production process associated with the use of a complex of economic resources. In particular, such resources should include natural resources, labor resources, financial resources. Moreover, speaking of waste as a result of production, it should be noted that it can act as assets for an industrial organization, provided that it can bring economic benefits. 


\section{Methods}

Waste as a result of production is a separate object of management of economic activities of an industrial organization, because it can be a relevant resource in its future activities, or operations with it lead to certain costs incurred by the company in the course of its management. Waste management can be expressed in a complex of operations related to disposal, recycling or dumping. All this indicates the need to develop a complex system of analytical support for waste management in order to comply with the basic provisions of the circular economy, which will ensure the environmental safety of organizations. In turn, the environmental safety management system of industrial organizations should be aimed at complying with the complex of social and economic interests of both business and society.

As you know, economic processes should be considered from the point of view of production and consumption, and each of these areas uses environmental resources to one degree or another and creates waste. A significant amount of material waste can be returned to production, and the remaining part is not recyclable (Mir, M. A., Ghazvinei, P. T., Sulaiman, N. M. N., Basri, N. E. A., Saheri, S., Mahmood, N. Z., ... \& Aghamohammadi, N. (2016)). Large percentage of the material waste can be returned to production through various types of effects, such as recycling, and components that could not be recycled are to be incinerated or disposed of in specially equipped sites. To increase the efficiency of interaction between the economy and the environment, it is necessary to develop such economic mechanisms that would, on the one hand, reduce the negative environmental impact of waste management activities on the environment, and on the other, increase the economic efficiency of this activity. Thus, waste, as a result of production, can, in turn, act as an economic resource for both industrial organization (through reuse) and other industrial organizations. In addition, waste management is associated with the creation of gross domestic product in the service sector, because the activities of waste-disposal organizations are quite profitable and form a special range of services. This allows us to speak about a new product - a service for disposal/recycling

This type of service is quite profitable. As for the United States, in Alaska the cost of disposal of hazardous waste costs 125 thousand dollars, while the total cost of the program with hazardous waste is 400 thousand dollars. (Rhyner, C. R., Schwartz, L. J., Wenger, R. B., \& Kohrell, M. G. (2017)). Switzerland has extensive experience in organizing this type of business. So, Switzerland recycles about $80 \%$ of its waste. There are 7 large waste recycling organizations: FERRO-Recycling (banks), IGORA (household aluminum), INOBAT (household batteries), PET-Recycling Switzerland (bottles), the SENS Foundation (electrical equipment), TEXAID (textiles) and VetroSwiss (glass), which are combined into Swiss Recycling (Kinnaman, T. C. (2017)).

\section{Results}

The disposal and recycling of industrial waste is a global problem in shaping the balanced development of the global community and ensuring sustainable development. In addition, this problem is more concerned with industrial organizations, because the world's reserves of various types of industrial wastes are growing exponentially.

Using real examples from world practice, it is shown that the technologies of waste disposal in the world to a large extent can reduce the costs of waste recycling compared to conventional landfill. These methods of disposal are not only environmentally friendly, but also cost-effective. For example, waste recycling using bio composting allows not only to safely dispode consumption waste, but also to maximally bring it into commercial use with a recycling depth of up to $90 \%$. The generalized world experience of using a combination of state and market management mechanisms allowed for more flexible use of these levers in the actual conditions in the sector (Nakashydze, L., \& Gil'orme, T. (2015); Androniceanu A., Drăgulănescu Irina-Virginia (2016); Rogalev, A.; Komarov, I.; Kindra, V.; Zlyvk, O. (2018); Vegera, S.; Malei, A.; Sapeha, I.; Sushko, V. (2018); Vegera, S.; Malei, A.; Trubovich, R. (2018)). Business development in the field of disposal/recycling is the basis, firstly, from an environmental point of view, for: a stabilization of the ecological situation and increase in the efficiency of using natural resources; secondly, an increase in the number of industrial organizations 
of small and medium-sized businesses, the creation of new work places, an increase in revenues to the state budget. In particular, in Germany, the activities of enterprises for the disposal and recycling of waste reaches 80 billion euros per year. In turn, in the United States, 122,000 organizations are engaged in this type of business, which employ more than 1600,000 people. (Blackman Jr, W. C. (2016)). Thus, currently established waste management mechanisms are not always effective from an environmental and economic point of view, they are not adapted to specific conditions. This leads to the problem of conceptual approaches development for ensuring waste management in the environmental safety of industrial organizations that have taken into account the requirements of today's world. This will allow to consider waste both from an environmental point of view, because its volumes in the environment are decreasing, and from an economic one, as it makes the organization more attractive for investments.

This prompts the study of waste as a result of the interaction of the organization with the environment. The problem of consumption waste management is one of the key issues in the field of environmental protection. Around the world, attempts are being made to effectively manage ever-increasing waste flows. Relevant in this regard is the consideration of the problem of consumption waste management from the standpoint of the concept of sustainable economic development, which provides for such development that meets the needs of the present, but does not jeopardize the ability of future generations to meet their own needs.

In turn, the basics of the circular economy today are the most popular in China, because this country has accumulated a large amount of industrial and household waste over the past decades. In China, the total annual volume of hazardous waste is about 11 million tons, of which industrial production accounts for more than 10 million tons, medical waste -650 thousand tons, radioactive waste -115300 tons (Zeng, X., Yang, C., Chiang, J. F., \& Li, J. (2017)). In addition to the above, in 1996-2004, 26,400,000 tons of hazardous waste were dumped without any handling or proper disposal (Zeng, X., Duan, H., Wang, F., \& Li, J. (2017)). As for the waste of Chinese production, more than 1 billion tons of it is generated annually, which is 5 times more than the annual volume of household waste (Yong, J. Y., Klemeš, J. J., Varbanov, P. S., \& Huisingh, D. (2016)). Thus, in China, three categories of waste are clearly defined: municipal, industrial and hazardous waste. The composition of municipal waste includes household, departmental, commercial, street garbage and unprocessed industrial waste.

Waste management combines both economic components and environmental, because the generation of waste is a chemical process, which, in turn, affects the environment. After all, waste in nature is geberated as a result of the openness of the global biotic circulation and represents the difference between the synthesis and destruction of organic matter in the biosphere, which is derived from the biotic circulation "into geology." Such is the nature of fuel and energy minerals: coal, oil, peat, natural gas. The "waste" of nature is localized and does not make a serious impact on the course of biospheric processes. A person attracts to the technosphere, to the "social metabolism" a huge amount of natural resources, which are both components of ecosystems and part of the components of the natural environment (Joshi, R., \& Ahmed, S. (2016)). 

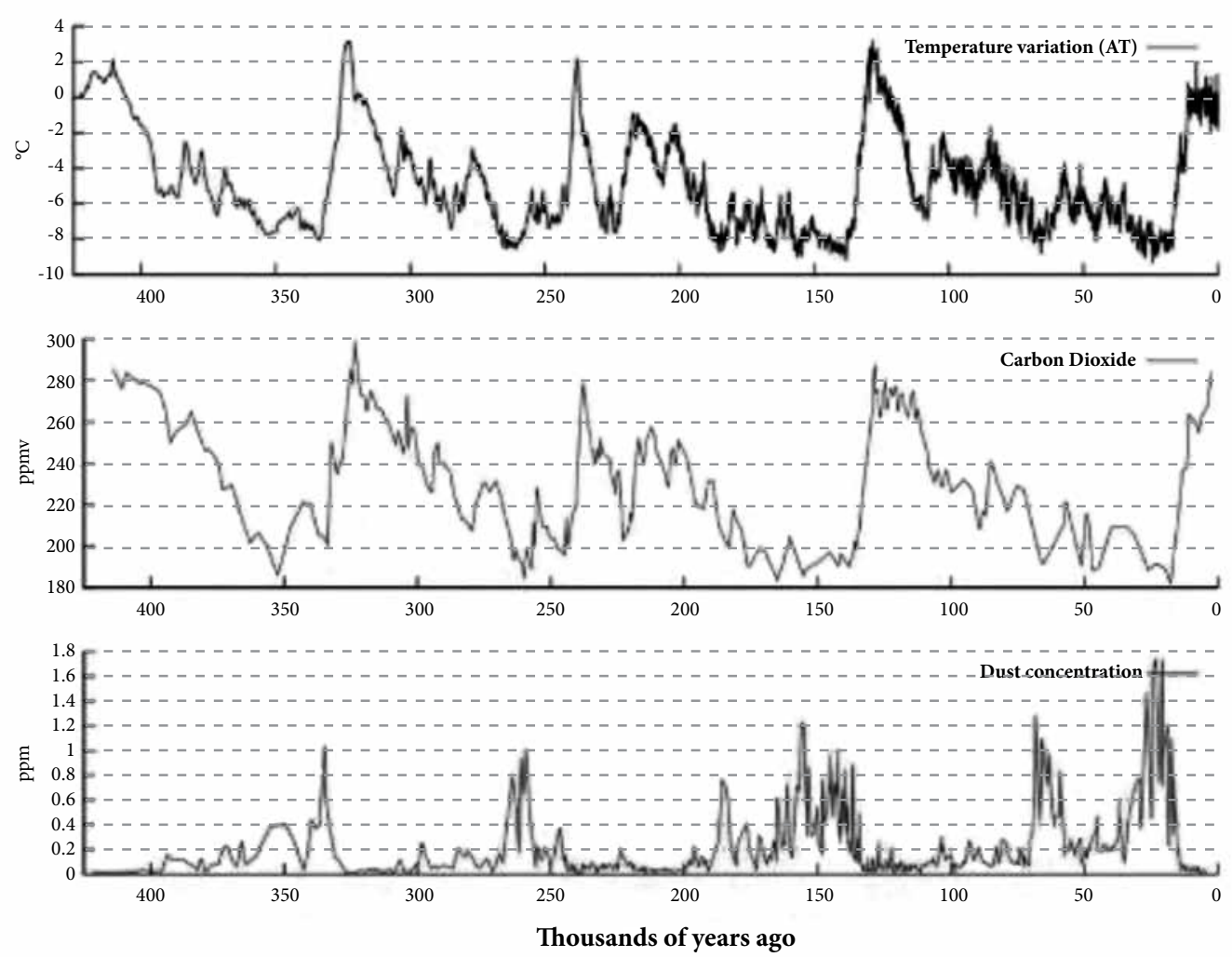

Figure 1. Changes in temperature, content of $\mathrm{CO} 2$ and dust in Antarctic glaciers over the past 450,000 years, according to data from Vostok station, Eurostat http://ec.europa.eu/eurostat/statistics-explained/index.php/Environmental_tax_statistics

The study of the human impact is carried out today through the calculation of the number of indicators, which are grouped in the ecological trace index. The basis for the calculation of these indicators is the study of the dynamics of the formation of CO2 (Figure 1) in the result of economic activity, especially when using fossil fuels, which can be demonstrated through the use of technological capabilities of the electronic resource of the World Bank.

The results of the assessment of the impact of environmental revenues on the indicators of sustainability of environmental development indicate that:

- Emissions of greenhouse gases increase in the year of receipt of environmntal taxes, and decrease with a lag in one year, and in the three-year perspective, this indicator is practically reduced to " 0 ";

- Renewable water resources remain at the same level in the year of receipt of taxes, but with the lag in one and three years the amount of renewals increases;

- the indicator of energy renewal decreases both in the year of receipt of taxes and with the lag in one and three years, that is, it has a positive dynamics;

- energy saving has the opposite dynamics, since with the lag in three years this figure reaches a critical point, unlike in the first year of tax receipts, where the indicator has a minimal value;

- the protection of biodiversity is similar to that of energy conservation, with a time lag of three years, although in the first two years this figure is decreasing;

- the indicator of biodiversity increases in the year of tax receipts and with the time lag in one year, and this indicator reaches the lowest point three years after the payment of environmental taxes.

Based on the above calculations, we can say that the most effective income from environmental taxes is used over the next three years. The indicators of sustainable ecological and human development with a growing summary reflect the positive dynamics of close interconnections in the three-year perspective. With regard the assessment of the relationship between these indicators and the parameters of sustainable development, this should be the basis for the development of environmental policies aimed at reduction the burden on the natural 
environment and targeted financing of the ecosystem protection through the revenues from environmental taxes. In order to assess the impact of financial and economic instruments on the state of the environment, it is proposed to conduct an assessment of the interconnection of environmental taxation parameters and indicators of environmental development using the example of the 16 European countries considered (Belgium, Bulgaria, Czech Republic, Denmark, Estonia, Spain, Croatia, Latvia, Lithuania, Hungary, Poland, Romania, Slovenia, Finland, Sweden, and United Kingdom). So, the ecological taxation to assess the relationship between indicators is proposed to be considered on the basis of three indicators:

- growth of environmental taxes - the ratio of increase in the sum of total environmental taxes for the current year to the level of the previous year, in $\%$;

- the share of environmental taxes in tax revenues - the ratio of the annual amount of total environmental taxes to the annual amount of aggregate tax revenues, in $\%$;

- the share of environmental taxes in GDP - the ratio of the annual amount of total environmental taxes to the annual GDP, in\%.

According to the results of the analysis of international methods for assessing the level of sustainable development and environmental parameters, a system of indicators was created, which can be influenced by the state through indicators of environmental taxation, namely, a sample totality of indicators of sustainability of human development:

- the length of a healthy life - the expectation of the length of a healthy life from the moment of birth in years;

- consumption - the difference between the environmental and carbon effects of human life on the environment, in ha;

- health care - health care per capita, US \$;

- mortality - the mortality rate per 1 thousand people;

- safety of access to water - percentage of population using safe drinking water supply services, $\%$;

- access to quality water sources $-\%$ of population with access to high-quality water resources.

Statistical data for calculations is presented in Appendix B. In order to assess the impact of environmental taxation on environmental development indicators, panel regression modelling tools using Stata software were used, which allowed to estimate the averaged level of links for a sample from 16 countries during the research period covering 2006-2016.

The results of the assessment of the impact of environmental taxation parameters and indicators of sustainability of human development on the basis of annual observations are presented in Table 1.

Table 1. Results of the assessment of the impact of environmental taxation parameters on indicators of sustainable human development for the period 2006-2016

\begin{tabular}{|c|c|c|c|c|c|c|}
\hline Factor signs & $\begin{array}{l}\text { Influence } \\
\text { factor }\end{array}$ & $\begin{array}{c}\text { Standard } \\
\text { error }\end{array}$ & $\mathrm{Z}$ & $\mathrm{P}>|\mathrm{z}|$ & $\begin{array}{c}\text { Lower } \\
95 \%\end{array}$ & Top 95\% \\
\hline \multicolumn{7}{|l|}{ Access to quality water sources } \\
\hline The share of environmental taxes in tax revenues & -0.813 & 0.483 & -1.680 & 0.092 & -1.759 & 0.133 \\
\hline The share of environmental taxes in GDP & -1.308 & 1.450 & -0.900 & 0.367 & -4.150 & 1.534 \\
\hline \multicolumn{7}{|l|}{ Safety of access to water } \\
\hline The share of environmental taxes in tax revenues & 0.263 & 0.108 & 2.430 & 0.015 & 0.051 & 0.476 \\
\hline The share of environmental taxes in GDP & 0.778 & 0.300 & 2.590 & 0.010 & 0.189 & 1.367 \\
\hline \multicolumn{7}{|l|}{ Mortality } \\
\hline The share of environmental taxes in tax revenues & 0.118 & 0.048 & 2.440 & 0.015 & 0.023 & 0.212 \\
\hline The share of environmental taxes in GDP & 0.224 & 0.159 & 1.410 & 0.158 & -0.087 & 0.535 \\
\hline \multicolumn{7}{|l|}{ Healthcare } \\
\hline The share of environmental taxes in tax revenues & -76.901 & 61.554 & -1.250 & 0.212 & -197.545 & 43.742 \\
\hline The share of environmental taxes in GDP & -266.504 & 193.560 & -1.380 & 0.169 & -645.875 & 112.868 \\
\hline
\end{tabular}




\begin{tabular}{|l|c|c|c|c|c|c|}
\hline The share of environmental taxes in tax revenues & -0.005 & 0.045 & -0.120 & 0.903 & -0.093 & 0.082 \\
\hline The share of environmental taxes in GDP & -0.073 & 0.135 & -0.540 & 0.589 & -0.338 & 0.192 \\
\hline The duration of a healthy life & -0.179 & 0.155 & -1.160 & 0.247 & -0.482 & 0.124 \\
\hline The share of environmental taxes in tax revenues & -0.061 & 0.472 & -0.130 & 0.898 & -0.987 & 0.865 \\
\hline The share of environmental taxes in GDP
\end{tabular}

Source: calculated by the authors based on data given by Eurostat

http://ec.europa.eu/eurostat/statistics-explained/index.php/Environmental_tax_statistics

The given results of the calculation show that there is a close connection between the presented indicators. Thus, the share of environmental taxes in GDP and total tax revenues has a significant impact on most indicators of sustainability of human development, namely access to high-quality water sources and safety of access to water and a healthy life expectancy. First of all, this is due to the process of renewal of these types of resources at the expense of these revenues, that is, reduction in the amount of harmful use of the environment, which indicates the complexity of environmental policies of countries. The effect of the environmental tax rates in the year after their application is somewhat worse, but also maintains a positive dynamics of interaction. The close correlation between the increase in environmental taxes and the costs of safe access to water points to an improvement in this indicator by improvement of the quality and availability of water resources (Table 2).

Table 2. Results of the assessment of the impact of environmental taxation parameters on indicators of sustainable human development for the period 2006-2016 with time lag of one year

\begin{tabular}{|c|c|c|c|c|c|c|}
\hline Factor signs & $\begin{array}{l}\text { Influence } \\
\text { factor }\end{array}$ & $\begin{array}{c}\text { Standard } \\
\text { error }\end{array}$ & $\mathrm{Z}$ & $\mathrm{P}>|\mathrm{z}|$ & $\begin{array}{c}\text { Lower } \\
95 \%\end{array}$ & $\begin{array}{l}\text { Top } \\
95 \%\end{array}$ \\
\hline \multicolumn{7}{|l|}{ Access to quality water sources } \\
\hline The share of environmental taxes in tax revenues & -0.337 & 0.515 & -0.650 & 0.513 & -1.346 & 0.672 \\
\hline The share of environmental taxes in GDP & 0.026 & 1.410 & 0.020 & 0.985 & -2.740 & 2.790 \\
\hline Increase in environmental taxes & 0.002 & 0.037 & 0.060 & 0.954 & -0.070 & 0.074 \\
\hline \multicolumn{7}{|l|}{ Safety of access to water } \\
\hline The share of environmental taxes in tax revenues & 0.135 & 0.110 & 1.220 & 0.223 & -0.082 & 0.351 \\
\hline The share of environmental taxes in GDP & 0.449 & 0.286 & 1.570 & 0.117 & 0.112 & 1.009 \\
\hline Increase in environmental taxes & -0.020 & 0.008 & -2.480 & 0.013 & -0.036 & -0.004 \\
\hline \multicolumn{7}{|l|}{ Mortality } \\
\hline The share of environmental taxes in tax revenues & 0.047 & 0.058 & 0.810 & 0.416 & -0.066 & 0.160 \\
\hline The share of environmental taxes in GDP & -0.022 & 0.170 & -0.130 & 0.899 & -0.354 & 0.311 \\
\hline Increase in environmental taxes & 0.000 & 0.004 & 0.120 & 0.908 & -0.007 & 0.008 \\
\hline \multicolumn{7}{|l|}{ Healthcare } \\
\hline The share of environmental taxes in tax revenues & -53.064 & 59.746 & -0.890 & 0.374 & -170.164 & 64.035 \\
\hline The share of environmental taxes in GDP & -63.344 & 174.858 & -0.360 & 0.717 & -406.058 & 279.371 \\
\hline Increase in environmental taxes & 2.829 & 3.865 & 0.730 & 0.464 & -4.746 & 10.404 \\
\hline \multicolumn{7}{|l|}{ Consumption } \\
\hline The share of environmental taxes in tax revenues & -0.014 & 0.048 & -0.300 & 0.767 & -0.108 & 0.079 \\
\hline The share of environmental taxes in GDP & -0.045 & 0.138 & -0.320 & 0.746 & -0.315 & 0.226 \\
\hline Increase in environmental taxes & 0.002 & 0.003 & 0.500 & 0.620 & -0.005 & 0.008 \\
\hline \multicolumn{7}{|l|}{ The duration of a healthy life } \\
\hline The share of environmental taxes in tax revenues & -0.178 & 0.166 & -1.070 & 0.284 & -0.504 & 0.148 \\
\hline The share of environmental taxes in GDP & -0.011 & 0.479 & -0.020 & 0.982 & -0.950 & 0.928 \\
\hline Increase in environmental taxes & -0.012 & 0.012 & -1.040 & 0.297 & -0.035 & 0.011 \\
\hline
\end{tabular}

Source: calculated by the authors based on data given by

(http://ec.europa.eu/eurostat/statistics-explained/index.php/Environmental_tax_statistics) 
That is, the effectiveness of the performance of indicators of the share of environmental taxes in GDP and tax revenues and the growth of environmental taxes remains the same in relation to all parameters of a stable level of human existence, which again speaks of the significant impact of such indicators on the sustainability of human development in this sample of countries.

The results of the assessment of the impact of environmental revenues on the indicators of sustainability of environmental development indicate that:

- Emissions of greenhouse gases increase in the year of receipt of environmental taxes, and decrease with a lag in one year, and in the three-year perspective, this indicator is practically reduced to " 0 ";

- Renewable water resources remain at the same level in the year of receipt of taxes, but with the lag in one and three years the amount of renewals increases;

- the indicator of energy renewal decreases both in the year of receipt of taxes and with the lag in one and three years, that is, it has a positive dynamics;

- energy saving has the opposite dynamics, since with the lag in three years this figure reaches a critical point, unlike in the first year of tax receipts, where the indicator has a minimal value;

- the protection of biodiversity is similar to that of energy conservation, with a time lag of three years, although in the first two years this figure is decreasing;

- the indicator of biodiversity increases in the year of tax receipts and with the time lag in one year, and this indicator reaches the lowest point three years after the payment of environmental taxes.

The author's vision of the formation of criteria for recognizing waste as economic resources in order to form the environmental safety management system, taking into account the main provisions of the concept of sustainable development and the need to introduce a circular economy, is as follows:

firstly, to group the criteria for control, disposal and use of the criterion - the existence of ownership of the economic resource. This criterion is economic and legal, because it determines the process of economic transactions, based on the legal form. It has a direct impact on the waste management of industrial organizations as a basis for ensuring their environmental safety. In addition, it determines the directions of formation of their reflection in the management system of both the industrial organization, the result of which is waste, and the waste-disposal organization, as well as the procedure for the interaction of these business entities;

secondly, based on the criterion of the ownership of an economic resource, the criterion of possibility of sale follows. In fact, this criterion is possible only with the right of ownership. In turn, all waste can be realized. However, the process of realization of waste is very specific, because this realization is not always associated with income. Thus, certain types of waste can be transferred free of charge to other organizations, including disposal organizations. In addition, there is waste, from which the organization seeks to get rid of in connection with its danger to the environment and human health. Therefore, the realization criterion should not be identified with the realization process at an industrial organization;

thirdly, the criterion for ensuring business processes / economic activities is quite wide, because it combines all types of activities (operational, financial, investment) and business processes (acquisition, production, sales). We propose to divide this criterion into two, namely: provision of types of economic activity and support of business processes, because these criteria determine the process of waste generation and the process of its use in the organization's activities, and each of them is associated with a set of waste management operations that can be associated with various activities and business processes;

fourthly, the criterion for obtaining results in the scientific economic literature is associated with making a profit from the use of economic resources.

However, in today's conditions, the economic component of the functioning of an industrial organization must be in harmony with the environmental one and, therefore, the enterprise should receive economic benefits and 
an environmental effect. This indicates the need to single out two criteria, namely: obtaining economic benefits and obtaining an environmental effect, with the first and second criteria having both a positive value and a negative one. All this depends on the establishment of a waste management system. In turn, it should be noted that the criterion of the environmental effect follows from the limited resources.

In general, the proposed criteria for the recognition of waste as economic resources (the existence of right of ownership, the possibility of realization, the economic benefits and the environmental effect ontaining) is the basis of a new understanding of this economic concept and the basis for shaping the behavior of economic agents in waste management. Considering this, there is a need to form new approaches to waste management as a component of the environmental safety of industrial organizations and, accordingly, to develop organizational and methodological provisions for analytical support. Current tendencies in the formation of a sustainable development of the country's economy and individual business entities lie in the rational use of natural resources and waste management. This significantly activates environmental activities aimed at ensuring the environmental safety of industrial organizations.

In addition to these sources of waste, it is necessary to allocate waste of an administrative nature at industrial organizations, that is, such that was generated in the departments of enterprise management, marketing service, and the like. Management of such waste is not of great importance in ensuring the environmental safety of an industrial organization. However, it may have an economic effect aimed at saving administrative costs. It should be noted that abnormal situations that may arise due to the instability of the external environment are of great importance in the economic activities management of an industrial organization. Such abnormal situations are emergency situations of a natural character, a technogenic character, a sociopolitical character.

The waste management system is manifested both at the internal level and at the level of economic relations between economic entities, in particular, between an industrial organization and a waste disposal organization. Thus, the main activity of the waste disposal organization is waste handling services, which include transportation, storage, recycling, disposal and dumping of waste. The interaction between these business entities leads to both material (movement of waste) and financial (payments for recycling services) flows. Thus, the place of waste in the system of management of economic activities of an industrial organization is determined by justifying the sources of its generation for all types of organization activities, business processes, conditions of operation and interaction with disposal organizations.

In particular, a determined process of waste generation is the basis for its identification by the place of origin in order to build the management information space. The mechanism for identifying waste depends on the management system, in particular in terms of production organization.

\section{Discussion}

The analysis made it possible to establish that the methods of expenses accounting and cost calculation of industrial products, which are used by industrial organizations of the engineering industry, are:

expenses accounting methods: actual cost (expenses are taken into account according to actual data obtained from primary documents) and regulatory method (expenses are taken into account in accordance with established standards provided by plans / budgets with subsequent recording of deviations in accordance with received primary documents on actual expenses incurred);

cost calculation methods: process method - when using a process method by enterprises of the industry, their technological process consists of stages. The positive point in the application of this method is that the collection of information on costs is less time consuming compared to the ordered method. In addition, the information reflected in the accounts is more transparent. The distribution of overhead costs for workshops is carried out more accurately (Tetiana, H., Chorna M., Karpenko L., Milyavskiy M. \& Drobyazko S. (2018)). Accordingly, the disadvantages are the inability to group costs by product, a significant amount of accounting records and the lack of information on the causes of deviations of actual costs from the standard;

ordered method - one of the main methods of calculating the cost of the heavy engineering organizations, 
where production costs are taken into account by individual or special orders. It involves treating each order as a separate accounting unit, for which direct material and labor costs are calculated, as well as overhead costs. At machine-building organizations, an ordered method is used with a semi-finished summary of foundry costs. According to the ordered method, due to the balance determination of the cost of finished products, if the loss of work in progress is not documented, it is automatically included in the cost of finished products of the enterprise, which leads to a simultaneous unreliability of the results of the calculation of the cost of production and expenses control;

and process and ordered method (integrated method, according to which the calculation is carried out on a separate order, within which the process stage is determined).

Thus, when using a process calculation method, waste is identified by its location, which will allow to manage separate technological cycles in the direction of reducing its volume and safe handling. According to an ordered method, you can determine the source - the product, which production leads to waste generation. Using the standard cost accounting method allows you to manage waste from the position of compliance with the standards of its generation. Considering the complexity of technological processes in industrial enterprises, we believe that it is advisable to allocate calculation areas for each process stage within individual workshops.

The calculation area is a conditional division of the technological process of a certain shop into separate subprocesses, which can be distinguished on the basis of a set of technological features, and the result of which is a certain semi-finished product. Waste is generated both in the workshops (stages) of the main production, and in the workshops of auxiliary production. In order to effectively manage waste in ensuring the economic and environmental safety of industrial organizations, it is advicable to identify the waste of both types of production. The stages of the main production characterize only the production process, in turn, the process of acquisition / receipt of tangible assets and the process of sale / disposal of tangible assets are provided by the auxiliary production workshops. In order to form a mechanism for identifying and recognizing waste, we suggest that industrial organizations should approve as an internal regulatory documents the following documents:

list of stages (workshops) at the whole enterprise and for individual orders in particular; list of calculation areas according to the stages (workshops) of the main and auxiliary production; classifiers of industrial production orders.

Sources and places of waste generation is only one of the components of waste identification and recognition in industrial organizations. Waste properties are of great importance in the mechanism of identification and recognition of waste. For the purpose of practical application of the developed waste classification, we offer its approval in the form of a waste classifier, which provides not only its separation according to classification criteria, but also according to its origin, that is, stages and calculation areas. For each type of waste, we suggest defining a cipher that, in terms of computerization, will allow automating its management. To form a waste classifier, it is advisable to use a classification matrix (Table 3).

Table 3. Waste classification matrix for identification and recognition purposes

\begin{tabular}{|c|c|c|c|c|c|}
\hline \multicolumn{2}{|c|}{ Places of waste generation } & \multicolumn{2}{|c|}{ Classification feature 1 } & \multicolumn{2}{|c|}{ Classification feature N } \\
\hline Stage & Site & Type 1.N & Type N.1 & Type N.N \\
\hline Workshop A & Site A.1 & Type 1.1 & $\ldots$ & $\ldots$ & $\ldots$ \\
\hline Workshop X & Site X.1 & $\ldots$ & $\ldots$ & $\ldots$ \\
\hline
\end{tabular}

Thus, the waste classifier built in such way is the basis for their identification and recognition by a management object. An identification mechanism that takes into account the type of waste, places and sources of its generation will allow to form an information space as the basis for making management decisions in the field of environmental safety of industrial organizations. 


\section{Conclusions}

For effective waste management in ensuring environmental safety of an industrial organization, it is necessary to approve a list of places of waste generation with responsible persons for its generation within the norms. We propose to form such a list as follows: first, the identification of all possible waste sites at an industrial organization with simultaneous approval of its list in accordance with the classifier. These places are the calculation areas of stages (workshops) of the main and auxiliary production; secondly, the approval of responsible persons at the sites of waste generation, whose main duties will include monitoring compliance with the norms of waste generation at the enterprise.

The approval of the responsible persons is carried out by making the relevant provisions in the job descriptions of the workshop managers or those responsible for the calculation area; thirdly, the approval of the norms of waste generation for each waste generation site with the procedure of revision in accordance with the production volumes and existing orders; fourthly, the development of a mechanism for identifying deviations in waste generation and its approval.

\section{References}

Androniceanu A., Drăgulănescu Irina-Virginia (2016). Survey on the buyers’ eco-responsibility and the urban white pollution, Environmental Engineering and Management Journal, February, 15(2), 481-487.

Blackman Jr, W. C. (2016). Basic hazardous waste management. Crc Press. URL: https://www.taylorfrancis.com/books/9781420032604

Cucchiella, F., D’Adamo, I., \& Gastaldi, M. (2017). Sustainable waste management: Waste to energy plant as an alternative to landfill. Energy Conversion and Management, 131, 18-31. https://doi.org/10.1016/j.enconman.2016.11.012

Dobrovič, J., Urbański, M., Gallo, P., Benková, E., Čabinová, V. (2018). Balanced scorecard concept as a tool of strategic management and its usage in the construction industry. Polish Journal of Management Studies, 18 (2), 59-72. http://doi.org/10.17512/pjms.2018.18.2.05

Dobrovolskienè, N.; Tvaronavičienė, M.; Tamošiūnienè, R. (2017). Tackling projects on sustainability: a Lithuanian case study. Entrepreneurship and Sustainability Issues, 4(4), 477-488. http://doi.org/10.9770/jesi.2017.4.4(6)

Eddelani, O., El Amrani El Idrissi, N., Monni, S. (2019). Territorialized forms of production in Morocco: provisional assessment for an own model in gestation. Insights into Regional Development, 1(1), 6-18. http://doi.org/10.9770/IRD.2019.1.1(1)

Haupt, M., Vadenbo, C., \& Hellweg, S. (2017). Do we have the right performance indicators for the circular economy?: insight into the Swiss waste management system. Journal of Industrial Ecology, 21(3), 615-627. URL: https://onlinelibrary.wiley.com/doi/full/10.1111/ jiec. 12506

Hilorme, T., Nazarenko Inna, Okulicz-Kozaryn, W., Getman, O. \& Drobyazko, S. (2018). Innovative model of economic behavior of agents in the sphere of energy conservation. Academy of Entrepreneurship Journal, Volume 24(3) URL: https://www.abacademies.org/ journals/month-september-year-2018-vol-24-issue-3-journal-aej-past-issue.html

Imran, M., Jian, Z., ul Haque, A., Urbański, M., Nair, S.L.S. (2018). Determinants of firm's export performance in China's automobile industry, Sustainability (Switzerland), 10 (11), art. no. 4078 http://doi.org/10.3390/su10114078

Joshi, R., \& Ahmed, S. (2016). Status and challenges of municipal solid waste management in India: A review. Cogent Environmental Science, 2(1), 1139434. URL: https://www.tandfonline.com/doi/abs/10.1080/23311843.2016.1139434

Kinnaman, T. C. (2017). The economics of residential solid waste management. Routledge. https://doi.org/10.4324/9781315240091

Kumar, Y., \& Maqbool, J. (2018). Waste management. URL: http://researcharchive.wintec.ac.nz/6542/

Mir, M. A., Ghazvinei, P. T., Sulaiman, N. M. N., Basri, N. E. A., Saheri, S., Mahmood, N. Z., ... \& Aghamohammadi, N. (2016). Application of TOPSIS and VIKOR improved versions in a multi criteria decision analysis to develop an optimized municipal solid waste management model. Journal of environmental management, 166, 109-115. https://doi.org/10.1016/j.jenvman.2015.09.028

Nakashydze, L., \& Gil'orme, T. (2015). Energy security assessment when introducing renewable energy technologies. Eastern-European Journal of Enterprise Technologies, 4/8(76), 54-59. URL: http://nbuv.gov.ua/UJRN/Vejpte_2015_4\%288\%29_10

Nikitina, M.G.; Pobirchenko, V.V.; Shutaieva, E.A.; Karlova, A.I. (2018). The investment component in a nation's economic security: 
the case of the Russian Federation, Entrepreneurship and Sustainability Issues, 6(2), 958-967. http://doi.org/10.9770/jesi.2018.6.2(32)

Novikovas, A.; Stankevičius, A. (2018). Municipal waste, as critical infrastructure, management: case of Lithuania, Journal of Security and Sustainability Issues, 8(2), 257-265. https://doi.org/10.9770/jssi.2018.8.2(12)

Ravindran, R., \& Jaiswal, A. K. (2016). Exploitation of food industry waste for high-value products. Trends in Biotechnology, 34(1), 58-69. https://www.sciencedirect.com/science/article/pii/S0167779915002267

Rhyner, C. R., Schwartz, L. J., Wenger, R. B., \& Kohrell, M. G. (2017). Waste management and resource recovery. CRC Press. URL: https://books.google.com.ua/books?hl=uk\&lr=\&id=PQZDDwAAQBAJ\&oi=fnd\&pg=PT20\&dq=waste+management\&ots=JykhktWg

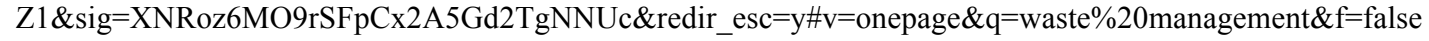

Rigamonti, L., Sterpi, I., \& Grosso, M. (2016). Integrated municipal waste management systems: An indicator to assess their environmental and economic sustainability. Ecological indicators, 60, 1-7. https://doi.org/10.1016/j.ecolind.2015.06.022

Rogalev, A.; Komarov, I.; Kindra, V.; Zlyvk, O. (2018). Entrepreneurial assessment of sustainable development technologies for power energy sector. Enterpreneurship and Sustainability Issues, 6(1), 429-445. http://doi.org/10.9770/jesi.2018.6.1(26)

Smaliukiene, R., Monni, S. (2019). A step-by-step approach to social marketing in energy transition. Insights into Regional Development, 1(1), 19-32. http://doi.org/10.9770/IRD.2019.1.1(2)

Tetiana, H., Chorna M., Karpenko L., Milyavskiy M. \& Drobyazko S. (2018). Innovative model of enterprises personnel incentives evaluation. Academy of Strategic Management Journal, 17(3) URL: https://www.abacademies.org/journals/month-june-year-2018-vol17-issue-3-journal-asmj-past-issue.html

Tetiana, H., Karpenko, L., Fedoruk, O., Shevchenko, I., \& Drobyazko, S. (2018). Innovative methods of performance evaluation of energy efficiency project. Academy of Strategic Management Journal, 17(2), 112-110. URL: https://www.abacademies.org/articles/ innovative-methods-of-performance-evaluation-of-energy-efficiency-projects-7067.html

Tetsman, I.; Bazienè, K.; Viselga, G. (2017). Technologies for sustainable circular business: using crushing device for used tires. Entrepreneurship and Sustainability Issues, 4(4), 432-440. http://doi.org/10.9770/jesi.2017.4.4(3)

Turner, D. A., Williams, I. D., \& Kemp, S. (2016). Combined material flow analysis and life cycle assessment as a support tool for solid waste management decision making. Journal of cleaner production, 129, 234-248. https://doi.org/10.1016/j.jclepro.2016.04.077

Vegera, S.; Malei, A.; Sapeha, I.; Sushko, V. (2018). Information support of the circular economy: the objects of accounting at recycling technological cycle stages of industrial waste. Entrepreneurship and Sustainability Issues, 6(1), 190-210. http://doi.org/10.9770/ jesi.2018.6.1(13)

Vegera, S.; Malei, A.; Trubovich, R. (2018). Accounting development of natural resources in organizations carrying out the disposal of municipal waste and biogas extraction in the context of the "green" economy. Entrepreneurship and Sustainability Issues, 6(1), 211-225. http://doi.org/10.9770/jesi.2018.6.1(14)

Vučijak, B., Kurtagić, S. M., \& Silajdžić, I. (2016). Multicriteria decision making in selecting best solid waste management scenario: a municipal case study from Bosnia and Herzegovina. Journal of Cleaner Production, 130, 166-174. https://doi.org/10.1016/j. jclepro.2015.11.030

Yong, J. Y., Klemeš, J. J., Varbanov, P. S., \& Huisingh, D. (2016). Cleaner energy for cleaner production: modelling, simulation, optimisation and waste management. Journal of Cleaner Production, 111, 1-16. https://doi.org/10.1016/j.jclepro.2015.10.062

Zaman, A. U. (2016). A comprehensive study of the environmental and economic benefits of resource recovery from global waste management systems. Journal of Cleaner Production, 124, 41-50. https://doi.org/10.1016/j.jclepro.2016.02.086

Zeng, X., Duan, H., Wang, F., \& Li, J. (2017). Examining environmental management of e-waste: China's experience and lessons. Renewable and Sustainable Energy Reviews, 72, 1076-1082. URL: https://doi.org/10.1016/j.rser.2016.10.015

Zeng, X., Yang, C., Chiang, J. F., \& Li, J. (2017). Innovating e-waste management: From macroscopic to microscopic scales. Science of the Total Environment, 575, 1-5. https://doi.org/10.1016/j.scitotenv.2016.09.078 
Short biographical note about the contributors at the end of the article:

Viktoriya Anishchenko, Ph.D. of Technical Sciences, Associate Professor, Head of Scientific and Research Center, Academy of the State Penitentiary Service, Chernihiv, Ukraine

ORCID ID: orcid.org/0000-0002-5062-3789

Viktoriya Marhasova, Doctor of Economic Sciences, Professor, Head of Department of Accounting, Taxation and Audit, Chernihiv National University of Technology, Chernihiv, Ukraine

ORCID ID: orcid.org/0000-0001-8582-2158

Andrii Fedorenko, Candidate of Economic Sciences, Associate Professor, Chernihiv National University of Technology, Chernihiv, Ukraine

ORCID ID: orcid.org/0000-0002-3754-6790

Mykhailo Puzyrov, Ph. D. in Law, Academy of the State Penitentiary Service, Chernihiv, Ukraine

ORCID ID: orcid.org/0000-0002-7814-9476

Oleh Ivankov, $\mathrm{Ph}$. D. in Law, Associate Professor, Academy of the State Penitentiary Service, Chernihiv, Ukraine ORCID ID: orcid.org/0000-0002-0709-704X

Register for an ORCID ID:

https://orcid.org/register

This work is licensed under the Creative Commons Attribution International License (CC BY). http://creativecommons.org/licenses/by/4.0/ 